\title{
Transient Complexes
}

\section{A NEW STRUCTURAL MODEL FOR THE ACTIVATION OF ADENYLATE CYCLASE BY HORMONE RECEPTORS (GUANINE NUCLEOTIDES/IRRADIATION INACTIVATION)}

\author{
By B. Richard MARTIN, Janet M. STEIN, Edwina L. KENNEDY, Christine A. DOBERSKA and \\ James C. METCALFE \\ Department of Biochemistry, University of Cambridge, Tennis Court Road, Cambridge CB2 1QW, U.K.
}

\author{
(Received 2 April 1979)
}

\begin{abstract}
1. The irradiation-inactivation procedure was used to study changes in the state of association of the protein components of adenylate cyclase in intact rat liver plasma membranes by measurement of alterations in the target size determined from the catalytic activity of the enzyme. 2. A decrease in target size at $30^{\circ} \mathrm{C}$ in response to $\mathrm{p}[\mathrm{NH}] \mathrm{ppG}$ (guanosine $5^{\prime}$-[ $\beta \gamma$-imido]triphosphate) or GTP was demonstrated, which we take to reflect the dissociation of a regulatory subunit. The effect of GTP is potentiated by glucagon. This effect is not observed at $0^{\circ} \mathrm{C}$. 3. An increase in target size was observed in response to glucagon in the absence of guanine nucleotides, which we take to reflect the association of glucagon receptor with adenylate cyclase. 4 . We propose a model for the activation of adenylate cyclase by glucagon in which the binding of the hormone to its receptor causes an initial association of the receptor with the catalytic unit of the enzyme and a regulatory subunit to form a ternary complex. The subsequent activation of the adenylate cyclase results from the dissociation of the ternary complex to leave a free catalytic unit in the activated state. This dissociation requires the binding of a guanine nucleotide to the regulatory subunit. 5. The effects of variation of temperature on the activation of adenylate cyclase by glucagon and guanine nucleotides were examined and are discussed in relation to the irradiation-activation data. 6. The effectiveness of hormones, guanine nucleotides and combinations of hormone and guanine nucleotides as activators of adenylate cyclase in both rat liver and rat fat-cell plasma membranes was studied and the results are discussed in relation to the model proposed, which is also considered in relation to the observations published by other workers.
\end{abstract}

The first step in the action of many hormones is the binding of the hormone to a protein receptor with a specific site on the outer surface of the plasma membrane. It has been suggested that, as a result of this hormone binding, the mobile independent hormone receptors became associated with catalytic units of adenylate cyclase to form complexes in which the enzyme is activated (Cuatrecasas, 1974). This hypothesis gained striking support from the cell-fusion experiments performed by Orly \& Schramm (1976), which demonstrated conclusively that hormone receptors must be able to move laterally within the plasma membrane to couple with the adenylate cyclase catalytic units, and that this coupling interaction was necessary for subsequent activation. Subsequent work by the same group has shown that this is a general phenomenon that can be observed with a wide variety of cell types (Schramm et al., 1977; Schulster et al., 1978). Direct support for a reversible structural association of the glucagon receptor with the catalytic subunit in rat liver plasma membranes has come from our previous estimations of the apparent target size of adenylate cyclase by the irradi- ation-inactivation technique (Houslay et al., 1977), where it was found that the addition of glucagon caused a large increase in target size.

In addition to the regulatory action of hormones, adenylate cyclase is also activated by GTP and other guanine nucleotides (Rodbell et al., 1975), including the GTP analogue p[NH]ppG (guanosine $5^{\prime}-[\beta \gamma-$ imido]triphosphate), which normally acts irreversibly. The regulation by guanine nucleotides and hormones appears to be interdependent, but their binding sites appear to be on protein components that are distinct from the catalytic unit. Pfeuffer \& Helmreich (1975) have shown that the adenylate cyclase activity of pigeon erythrocyte plasma membranes can be separated from $\mathrm{p}[\mathrm{NH}] \mathrm{ppG}$-binding proteins by gel chromatography of dispersions of the membranes in detergent or by affinity chromatography on GTP immobilized on agarose beads (Pfeuffer, 1977). Ross et al. (1978) have demonstrated that the adenylate cyclase and the guanine nucleotide regulatory activity have different sensitivities to heat and $N$-ethylmaleimide. They have also been able to resolve these two functions into different cultural 
cell lines. Furthermore glucagon-binding fractions in rat liver plasma membranes have been found to be easily separable from $\mathrm{p}[\mathrm{NH}] \mathrm{ppG}$-sensitive adenylate cyclase by similar techniques (Welton et al., 1977). It therefore seems likely that there are at least three different functional components in the system.

Here we have estimated the apparent target sizes of adenylate cyclase to determine how glucagon and guanine nucleotides affect the association of the regulatory components with the catalytic unit. The results show that full activation of the catalytic unit requires its dissociation from both of the regulatory components, but also confirm that a transitory association of all three components precedes the release of the free, fully activated, catalytic unit.

\section{Materials and Methods}

\section{Materials}

ATP, cyclic AMP, GTP, p[NH]ppG and creatine phosphokinase were obtained from Boehringer, Lewes, East Sussex, U.K. Phosphocreatine was obtained from Sigma (London) Chemical Co., Kingston-upon-Thames, Surrey KT2 7BH, U.K. Glucagon was a gift from Dr. W. Bromer, Eli Lilly, Indianapolis, IN, U.S.A. Cyclic $\left[{ }^{3} \mathrm{H}\right] \mathrm{AMP}$ and $\left[{ }^{32} \mathrm{P}\right] \mathrm{P}_{\mathbf{i}}$ were obtained from The Radiochemical Centre, Amersham, Bucks. HP7 9LL, U.K. [ $\alpha{ }^{32}$ P]ATP was prepared by the method of Martin \& Voorheis (1977).

\section{Plasma membranes}

Rat liver plasma membranes were prepared by the method of Pilkis et al. (1974). Rat fat-cell plasma membranes were prepared by the method of McKeel \& Jarett (1970).

\section{Assay of adenylate cyclase activity}

Activity was determined by the method of Salomon et al. (1974). Incubations were for $20 \mathrm{~min}$ at $30^{\circ} \mathrm{C}$ in $0.1 \mathrm{ml}$ containing $25 \mathrm{~mm}$-Tris/ $\mathrm{HCl}$ buffer, $\mathrm{pH} 7.4$, $0.5 \mathrm{mM}-\mathrm{ATP}, 1 \mu \mathrm{Ci}$ of $\left[\alpha^{-32} \mathrm{P}\right] \mathrm{ATP}, 0.1 \mathrm{mM}$-cyclic AMP, $10 \mathrm{mM}-\mathrm{MgCl}_{2}, 1 \mathrm{~mm}$-dithiothreitol, $5 \mathrm{~mm}-$ phosphocreatine and 5 units of creatine kinase.

\section{Irradiation-inactivation procedure}

Rat liver plasma membranes $(0.1 \mathrm{mg}$ of protein) were preincubated at either $30^{\circ} \mathrm{C}$ or $0^{\circ} \mathrm{C}$ in $0.2 \mathrm{ml}$ of a medium containing $25 \mathrm{mM}-\mathrm{Tris} / \mathrm{HCl}$ buffer, $\mathrm{pH} 7.4$, $0.1 \mathrm{~mm}$-ATP, $0.1 \mathrm{~mm}$-cyclic AMP, $10 \mathrm{~mm}-\mathrm{MgCl}_{2}$, $5 \mathrm{~mm}$-phosphocreatine and 5 units of creatine kinase, with further additions as described in the legends to Figures and Tables. The incubation was stopped after $10 \mathrm{~min}$ by rapidly freezing the mixture by immersing the tubes in liquid $\mathbf{N}_{\mathbf{2}}$. The frozen incubation mixtures were freeze-dried, and the tubes were gassed with $\mathrm{O}_{2}$-free $\mathrm{N}_{2}$ and sealed. The samples were then irradiated in an electron beam by using the $15 \mathrm{MeV}$ linear accelerator at Addenbrooke's Hospital, Department of Radiotherapeutics, University of Cambridge. After irradiation the samples were resuspended in $0.2 \mathrm{ml}$ of a $0.1 \mathrm{~mm}$ solution of $\mathrm{p}[\mathrm{NH}] \mathrm{ppG}$, and the adenylate cyclase activity was determined as described above in the presence of $0.1 \mathrm{mM}-\mathrm{p}[\mathrm{NH}] \mathrm{ppG}$, a $20 \mathrm{~min}$ incubation being used. More than $90 \%$ of the original adenylate cyclase activity was recovered in samples that had not been irradiated.

\section{Determination of apparent target sizes}

Target sizes were estimated from a plot of the logarithm of the remaining activity against the irradiation dose (Figs. 1 and 2). A linear relationship is obtained for a homogeneous species and the slope is proportional to the target size. The values of the target sizes were calculated from the relationship determined by Kepner \& Macey (1968):

$$
\text { Mol.wt. }=6.5 \times 10^{5} / D_{37}
$$

where $D_{37}$ is the dose in Mrads at which $37 \%$ of the activity remains.

\section{Evaluation of the irradiation-inactivation method}

There are relatively few independent determinations of the molecular weights of membrane proteins, so that it is difficult to assess the reliability of the method in determining the absolute values of the molecular weight of membrane proteins. The method is, however, a reliable approach for determining relative changes in molecular weights. To check for day-today variations in calibration of the irradiation dose, freeze-dried human erythrocyte plasma membranes were irradiated and assayed for acetylcholinesterase activity by the method of Ellman et al. (1961). The mean target size for acetylcholinesterase was $70000 \pm$ 3000 ( \pm S.E.M., nine observations), in close agreement with the value reported by Levinson \& Ellory (1973). If the target size for acetylcholinesterase differed from this value by more than $10 \%$ the experiment was discarded. This occurred in about $10 \%$ of the experiments. The ratios of the target sizes for each state of adenylate cyclase to acetylcholinesterase were constant. In our earlier study (Houslay et al., 1977) we found somewhat lower values for the target size of adenylate cyclase. We did not use the control described above in that study, and the values were thus probably an underestimate. However, the proportional changes in target size in response to various effectors were very similar in both studies. 


\section{Results and Discussion}

Analysis of subunit interactions by irradiation inactivation

The method of irradiation inactivation offers a unique opportunity to measure changes in the state of association of membrane proteins in situ as reflected by changes in their apparent target size.
We have found that there is a striking contrast in the effects of both glucagon and guanine nucleotides on the apparent target sizes of adenylate cyclase when compared at $30^{\circ} \mathrm{C}$ and at $0^{\circ} \mathrm{C}$ (Fig. 1). At $30^{\circ} \mathrm{C}$, $\mathrm{p}[\mathrm{NH}] \mathrm{ppG}(0.1 \mathrm{~mm})$ caused a significant decrease in the target size of adenylate cyclase by $34 \pm 1.7 \%$ (mean \pm S.E.M., six observations), but at $0^{\circ} \mathrm{C}$ the nucleotide had no detectable effect. Glucagon $(1 \mu \mathrm{M})$
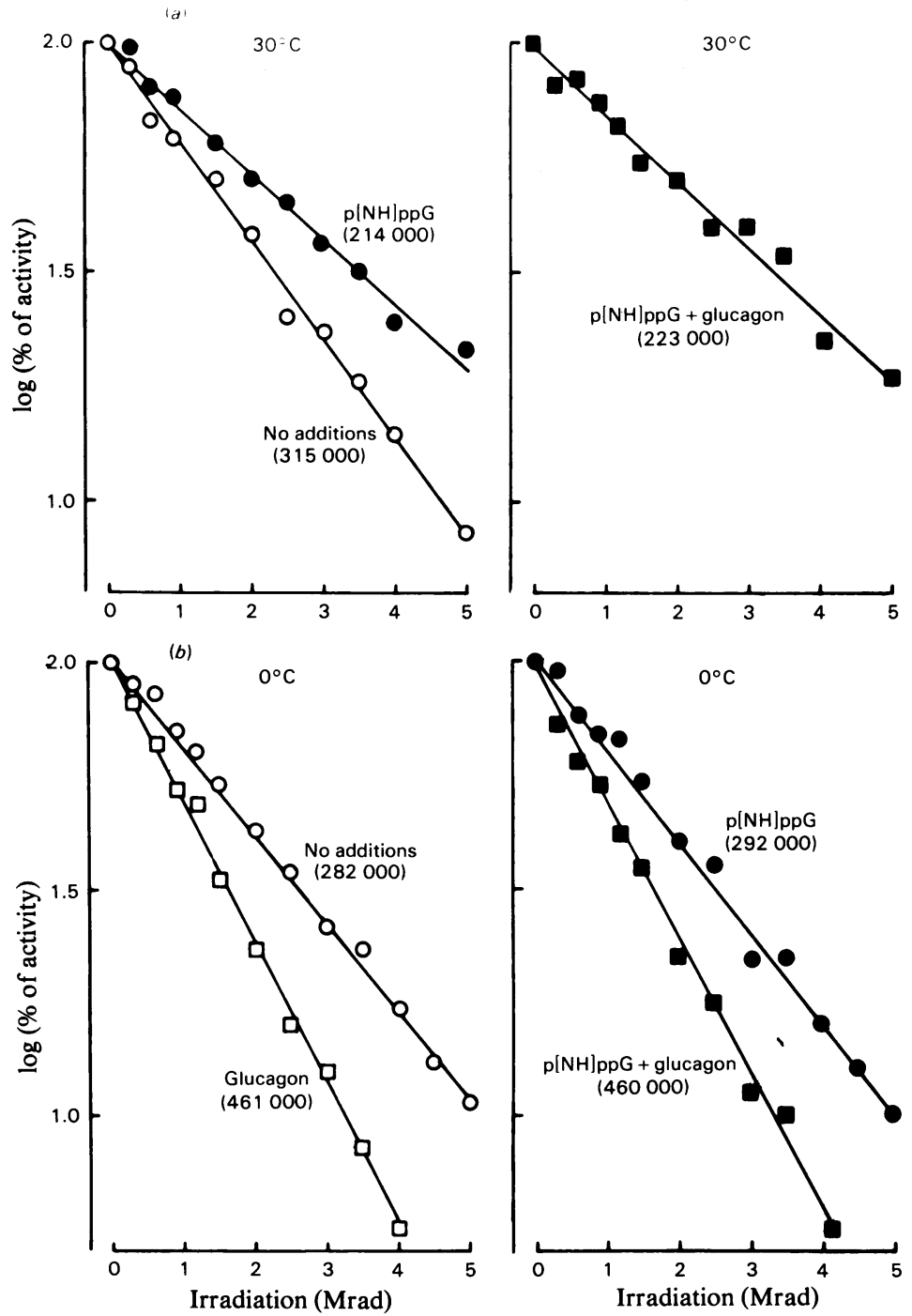

Fig. 1. Effect of glucagon and $p[N H] p p G$ on irradiation inactivation of adenylate cyclase

Rat liver plasma membranes (0.1 mg of protein), prepared by the method of Pilkis et al. (1974), were preincubated as described in the Materials and Methods section at either $30^{\circ} \mathrm{C}(a)$ or $0^{\circ} \mathrm{C}(b)$. Further additions were: 0 , no additions; $\bullet, \mathrm{p}[\mathrm{NH}] \mathrm{ppG}(0.1 \mathrm{mM}) ; \square$, glucagon $(1 \mu \mathrm{M}) ; \mathbf{\square}, \mathrm{p}[\mathrm{NH}] \mathrm{ppG}(0.1 \mathrm{mM})+$ glucagon $(1 \mu \mathrm{M})$. Details of the irradiation procedure and assay for adenylate cyclase are given in the Materials and Methods section. The numbers in parentheses indicate target sizes.

Vol. 184 
together with p[NH]ppG $(0.1 \mathrm{~mm})$ caused a similar decrease in target size at $30^{\circ} \mathrm{C}$ of $33 \pm 1.3 \%$ (four observations), but at $0^{\circ} \mathrm{C}$ glucagon alone, or together with $\mathrm{p}[\mathrm{NH}] \mathrm{ppG}$, caused a marked increase in target size of $60 \pm 2.5 \%$ (three observations), confirming our previous observation of the effect of glucagon at $0^{\circ} \mathrm{C}$ (Houslay et al., 1977). The values of the target sizes are shown on Fig. 1. Although it is uncertain how closely these values will relate to the absolute value of the molecular weights (see the discussion above), we note that they fall within the range of molecular weights estimated for adenylate cyclase by other methods. For adenylate cyclase from rat liver plasma membranes molecular weights have been determined by ultracentrifugation (160000; Neer, 1974), by gel electrophoresis (200000; Newby et al., 1978) and by gel filtration of membranes in Lubrol (670000; Welton et al., 1978).

The physiological nucleotide GTP (1 mM) caused the same decrease in target size as did p[NH]ppG at $30^{\circ} \mathrm{C}$, provided that glucagon was also present (Fig. 2). In the absence of glucagon, GTP was less effective in producing the decrease in target size than $\mathrm{p}[\mathrm{NH}] \mathrm{ppG}$ and non-linear plots were obtained. This probably indicates the presence of a mixture of species, and is consistent with an incomplete dissociation of the regulatory component, which binds guanine nucleotides, from the catalytic unit (Fig. 2).

\section{Model of hormone action}

We propose a model for the interaction of the catalytic unit of adenylate cyclase with its two regulatory components that is illustrated in Fig. 3. This is the simplest model compatible with the changes in apparent target size produced by glucagon and guanine nucleotides. We suggest that the effect of $\mathrm{p}[\mathrm{NH}] \mathrm{ppG}$ at $30^{\circ} \mathrm{C}$ is to cause the dissociation from the catalytic unit $(C)$ of a regulatory component $(G)$ that is assumed to bind guanine nucleotides (Fig. 3a). The free catalytic unit $(C)$ is then fully activated. The dissociation of component (G) from component (C) is unaffected by the independent glucagon receptors $(\mathrm{R})$, which in the absence of hormone are not structurally coupled to the catalytic unit (C) or to the guanine nucleotide-binding component (G). This effect of p[NH]ppG is essentially irreversible and complete. In contrast, the effect of GTP is reversible and incomplete in that an equilibrium is established between the activated dissociated state (C) and the inactive associated state (CG). This is consistent with the non-linear inactivation plot (Fig. 2b) and the smaller activation of the enzyme by GTP than by $\mathrm{p}[\mathrm{NH}] \mathrm{ppG}$ (Table $1 a$ ). The effects of guanine nucleotides on target size were very temperaturedependent and dissociation of the complex (CG) did not occur at $0^{\circ} \mathrm{C}$.

The model for the action of glucagon is summarized
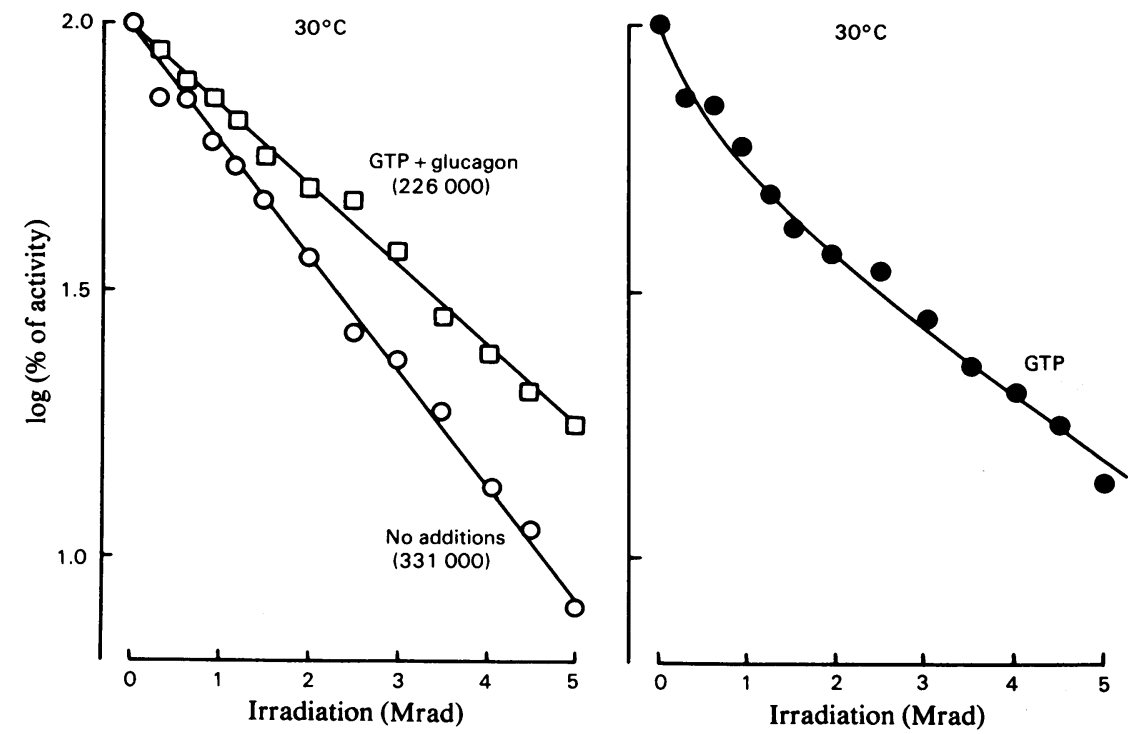

Fig. 2. Effect of glucagon and GTP on irradiation inactivation of adenylate cyclase

Rat liver plasma membranes were preincubated for $10 \mathrm{~min}$ at $30^{\circ} \mathrm{C}$ with additions as follows: $O$, no additions; $\bullet$, GTP $(1 \mathrm{mM})$; [], GTP $(1 \mathrm{mM})+$ glucagon $(1 \mu \mathrm{M})$. Details of the irradiation-inactivation procedure and assay of adenylate cyclase activity are given in the Materials and Methods section. The numbers in parentheses indicate target sizes. 

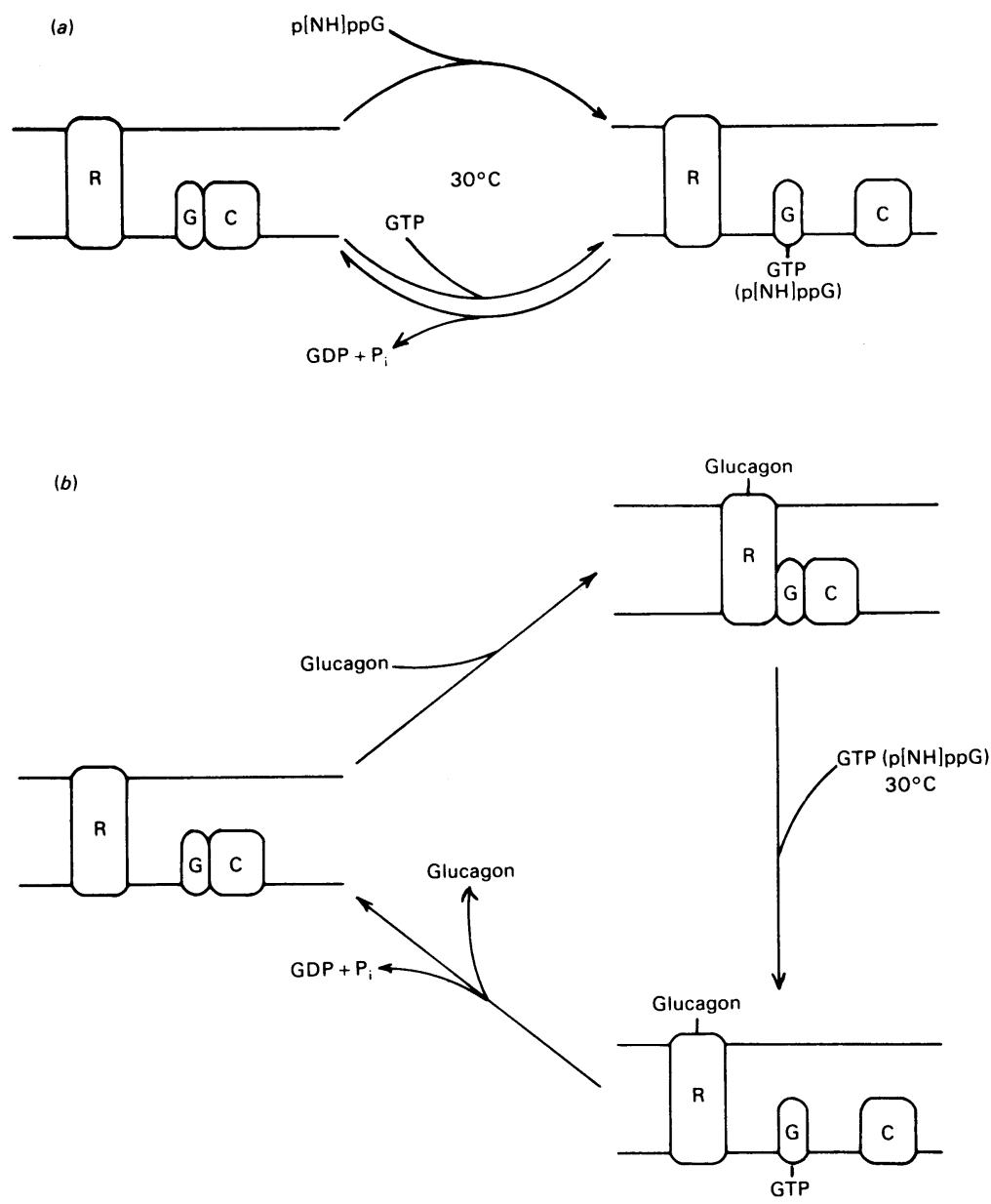

Fig. 3. Model of the mechanism of activation of adenylate cyclase by glucagon and guanine nucleotides

The Figure describes the model proposed for alterations in the aggregation state of adenylate cyclase during activation by guanine nucleotides $(a)$ or by guanine nucleotides in the presence of glucagon $(b)$. The glucagon receptor is represented by $R$, the catalytic unit by $C$ and the GTP-binding unit by $G$.

in Fig. 3(b). In the presence of glucagon the receptor $(\mathrm{R})$ associates with the (CG) complex to form a ternary complex (CGR). This species (CGR) can be detected at $0^{\circ} \mathrm{C}$ through the increase in apparent target size of adenylate cyclase (Fig. 1 b). At $30^{\circ} \mathrm{C}$, in the presence of either p[NH]ppG or GTP, the ternary complex (CGR) dissociates to release the fully activated catalytic unit (C). Glucagon and GTP together are able to produce complete dissociation of the free activated catalytic unit (C) from the regulatory components (G) and (R), whereas GTP alone will only partially dissociate the complex (CG). Thus we propose that the normal effect of the hormone is to facilitate the action of the physiological activator GTP in causing the release of the free activated catalytic unit (C) of the enzyme.

There are at least two features of the model that are at present undefined. Since we have made no determinations in this study of the target size of either the hormone receptor or the guanine nucleotide-binding protein, we are unable to say whether the ternary complex immediately dissociates completely to give free component $(G)$, receptor $(R)$ and component $(C)$, or whether component $(G)$ and receptor $(R)$ remain associated as a complex (GR). Under physiological conditions the complex (CG) must eventually be regenerated, and this implies that free component (G) must become available. It is therefore simpler to 
assume that complete dissociation of the ternary complex occurs as in Fig. 3(b).

Tolkovsky \& Levitzki (1978) have also suggested that the hormone receptor dissociates from the catalytic unit of adenylate cyclase on the basis of a study of the kinetics of activation of turkey erythrocyte plasma-membrane adenylate cyclase by $\beta$-adrenergic agonists.

The second point is the nature of the guanine nucleotide-binding protein. Sevilla \& Levitzki (1977) and Rendell et al. (1977) have suggested that the reversal of the activation of adenylate cyclase by GTP requires the hydrolysis of GTP to GDP and $P_{i}$. Cassell \& Selinger (1976) have reported the existence of a specific guanosine triphosphatase in turkey erythrocyte plasma membranes that they suggest is involved in the action of guanine nucleotides on adenylate cyclase. If the subunit $(G)$ is a guanosine triphosphatase, this would provide a simple explanation for the marked difference in the responses of the enzyme to GTP and p[NH]ppG. We suggest that the hydrolysis of GTP to GDP and $P_{1}$ by the $(G)$ subunit may allow the reassociation of component $(G)$ with the catalytic unit (C), to reverse the activation (Fig. $3 b)$. In contrast, $\mathrm{p}[\mathrm{NH}] \mathrm{ppG}$ is resištant to hydrolysis, and its effects are irreversible.

\section{Direct biochemical predictions from the model}

There are several immediate biochemical predictions from the model that can easily be tested.

Since we propose that $\mathrm{p}[\mathrm{NH}] \mathrm{ppG}$ alone can dissociate the regulatory component $(G)$ completely from the catalytic unit (C) and that the free catalytic unit is the fully active state of the enzyme, it follows from this model that glucagon should not cause any additional activation of the enzyme in the presence of optimal concentrations of $\mathrm{p}[\mathrm{NH}] \mathrm{ppG}$. In Table $1(b)$ we show that there was no further increase in adenylate cyclase activity on addition of glucagon $(1 \mu \mathrm{M})$ in the presence of $\mathrm{p}[\mathrm{NH}] \mathrm{ppG}(0.1 \mathrm{mM})$ provided that the membranes were pretreated with $\mathrm{p}[\mathrm{NH}] \mathrm{ppG}$ at $30^{\circ} \mathrm{C}$ for $10 \mathrm{~min}$ to allow full activation to occur before the addition of the hormone. In agreement with many previous reports (Rodbell et al., 1975; Birnbaumer, 1973), we found that when glucagon and p[NH]ppG were added simultaneously there was an additional increase in activity compared with the activation by $\mathrm{p}[\mathrm{NH}] \mathrm{ppG}$ alone (Table $1 a$ and Fig. 4). This can be attributed to the well-defined delay in the response to $\mathrm{p}[\mathrm{NH}] \mathrm{ppG}$ that has been shown to be abolished by glucagon (Rodbell et al., 1975). Thus it appears that the hormone can increase the rate at which full activation by $\mathrm{p}[\mathrm{NH}] \mathrm{ppG}$ is achieved, but 'does not affect the final extent of that activation.

The irradiation-inactivation data show that, in the presence of glucagon, GTP causes complete dissociation of the complex (CG) to the free catalytic unit (C) and the free guanine nucleotide-binding unit (G). From this we would expect that GTP together with glucagon should cause maximal activation of the enzyme, and this is confirmed by the results given in Table 1(a). A further requirement of the model is that at $0^{\circ} \mathrm{C}$ little or no activation of adenylate cyclase should be observed with any effector or combination of effectors, since at this temperature the complexes (CGR) and (CG) are apparently unable to dissociate (Fig. 1b) to give the free catalytic unit (C). It is consistent with this requirement that the maximal activation observed with glucagon $(1 \mu \mathrm{M})$ together with p[NH]ppG $(0.1 \mathrm{~mm})$ was $800 \%$ at $30^{\circ} \mathrm{C}$, whereas at $0^{\circ} \mathrm{C}$ the corresponding activation was only $50 \%$ (Fig. 4).

The model predicts that, in the absence of guanine nucleotides, glucagon would cause an increase in the target size at $30^{\circ} \mathrm{C}$ by formation of the ternary complex (CGR). However, under these conditions a nonlinear irradiation plot was obtained (not shown), indicating a partial dissociation of the ternary complex (CGR) to give a mixture of species of different compositions. This is to be expected, since at $30^{\circ} \mathrm{C}$ glucagon

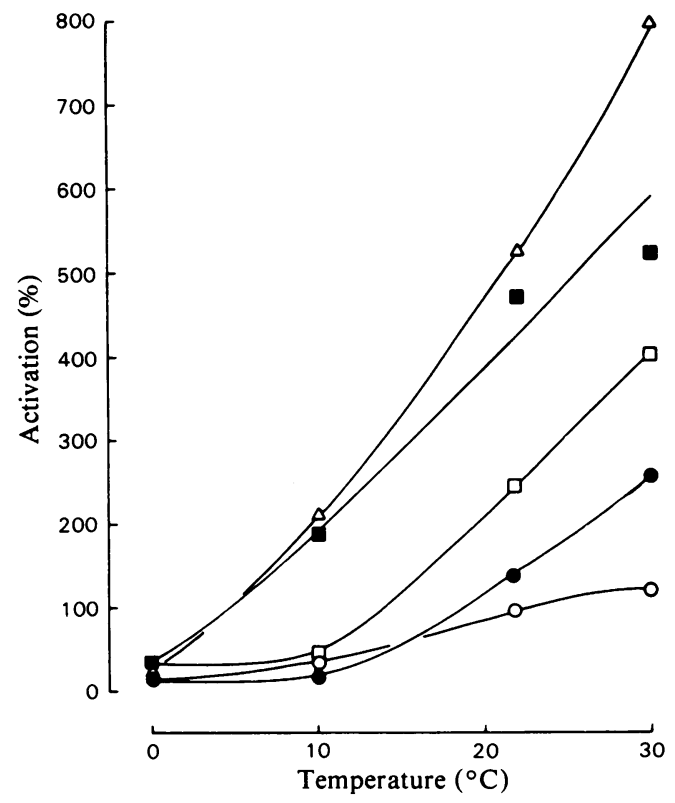

Fig. 4. Effect of variation of temperature on the activation of adenylate cyclase by glucagon and guanine nucleotides The adenylate cyclase activity of rat liver plasma membranes was determined as described in the Materials and Methods section at various temperatures with the following additions: O, GTP (1 mM); $\square$, p[NH]ppG $(0.1 \mathrm{~mm}), \bullet$, glucagon $(1 \mu \mathrm{M})$; $\mathbf{n}$, glucagon $(1 \mu \mathrm{M})+\mathrm{GTP}(1 \mathrm{mM}) ; \Delta$, glucagon $(1 \mu \mathrm{M})+$ $\mathrm{p}[\mathrm{NH}] \mathrm{ppG}(0.1 \mathrm{mM})$. 
alone causes a partial activation of adenylate cyclase (Table $1 a$ ), which may be attributable to the presence of small amounts of GTP in either the membrane preparation or the ATP used in the experiment (Kimura et al., 1976); another possibility is that ATP may itself act as a weak analogue of GTP (Birnbaumer et al., 1972) to cause a partial dissociation of the (CGR) complex. A possible approach to the detection of the ternary complex at $30^{\circ} \mathrm{C}$ would be to employ a suitable competitive antagonist of glucagon. Our previous data indicated that des-histidine-glucagon (prepared by Edman degradation so that the lysine side chain was modified) caused a structural coupling of the receptor to the catalytic unit without causing activation (Houslay et al., 1976, 1977). We predict therefore that this agent should permit the detection of the ternary complex at $30^{\circ} \mathrm{C}$.

The model offers a simple explanation for some observations made by Rodbell and co-workers (Rodbell et al., 1974, 1975; Lad et al., 1977) on the effects of GTP on the binding of glucagon to its receptor. They found that in the absence of added GTP the dissociation of glucagon from its receptor is very slow and that the rate of dissociation is greatly increased by the presence of GTP. Our model predicts that, in the absence of GTP and in the presence of glucagon, the predominant species will be the ternary complex (CGR), which has low activity. We suggest that the rate of dissociation of glucagon from the ternary complex (CGR) is low. In the presence of GTP, the ternary complex dissociates to release the free receptor $(R)$, and we suppose that the rate of dissociation of glucagon from the receptor $(R)$ is high.

Rodbell et al.(1974)also found that at physiological concentrations of glucagon ( $2 \mathrm{nM}$ or less) the addition of GTP resulted in a doubling of the adenylate cyclase activity and the amount of glucagon bound to receptors was decreased to less than $20 \%$. It is therefore likely that in the presence of GTP one receptor is able to activate several catalytic units. We suggest that, when the ternary complex (CGR) is dissociated by the action of GTP, the free hormone receptor that is released is available to recombine with a new (CG) complex and initiate a further turn of the activation cycle. The end effect is that one receptor promotes the release of many free activated catalytic units, because the dissociation rate of the complex (CGR) is now high compared with the rate of reassociation of components $(C)$ and $(G)$ to give the (CG) complex. We point out that the model we have proposed on structural grounds shows a striking parallel with the model proposed by Rendell et al. (1977) on kinetic grounds.

Finally, if the model is generally applicable to the activation of adenylate cyclase by hormones, we would expect that other hormones should have no effect on adenylate cyclase that had been fully activated by $\mathrm{p}[\mathrm{NH}] \mathrm{ppG}$. We therefore examined the effects of corticotropin, glucagon and L-isoproterenol on the adenylate cyclase activity of fat-cell plasma membranes preincubated with optimal $\mathrm{p}[\mathrm{NH}] \mathrm{ppG}$ $(0.1 \mathrm{~mm})$. None of the hormones gave any additional activation (Table 2 ).

The approach we have used in this study has the unique advantage that it has been possible to determine alterations in the physical state of adenylate cyclase in the intact membrane and to relate them to changes in the biochemical behaviour of the enzyme.

The model we have proposed suggests that the association of the hormone receptor with the catalytic unit is transitory. This type of model has previously been suggested on theoretical grounds by Tolkovsky \& Levitzki (1978), who provided further support for their proposals based on studies of the kinetics of the activation of turkey erythrocyte plasma-membrane adenylate cyclase by catecholamines. The data we have now presented provides

Table 1. Effects of guanine nucleotides and glucagon on adenylate cyclase in rat liver plasma membranes Adenylate cyclase activity was determined in rat liver plasma membranes as described in the Materials and Methods section. Membranes either without pretreatment $(a)$ or pretreated with $\mathrm{p}[\mathrm{NH}] \mathrm{ppG}(0.1 \mathrm{mM})(b)$ were incubated for $10 \mathrm{~min}$ at $30^{\circ} \mathrm{C}$ in $\mathrm{MgCl}_{2}(10 \mathrm{mM})$. Results are means \pm S.E.M. for three observations.

Additions to assay

(a) No preincubation

None

GTP (1 mM)

p[NH]ppG (0.1 mM)

Glucagon $(1 \mu \mathrm{M})$

Glucagon $(1 \mu \mathrm{M})+\mathrm{GTP}(1 \mathrm{mM})$

Glucagon $(1 \mu \mathrm{M})+\mathrm{p}[\mathrm{NH}] \mathrm{ppG}(0.1 \mathrm{mM})$

(b) Preincubated with p[NH]ppG (1 mM) $\mathrm{p}[\mathrm{NH}] \mathrm{ppG}(0.1 \mathrm{~mm})$

p[NH]ppG $(0.1 \mathrm{~mm})+$ glucagon $(1 \mu \mathrm{M})$
Adenylate cyclase

(nmol/20 min per $\mathrm{mg}$ of protein)
$0.465 \pm 0.012$

$1.40 \pm 0.047$

$3.69 \pm 0.126$

$1.16 \pm 0.014$

$4.64 \pm 0.008$

$5.01 \pm 0.057$

$5.11 \pm 0.136$

$5.15 \pm 0.104$

Vol. 184 
Table 2. Effect of hormones on adenylate cyclase activity in rat fat-cell plasma membranes Rat fat-cell membranes were incubated for $10 \mathrm{~min}$ at $30^{\circ} \mathrm{C}$ in the presence of p $[\mathrm{NH}] \mathrm{ppG}(0.1 \mathrm{~mm})$ and $\mathrm{MgCl}_{2}(10 \mathrm{mM})$. They were then assayed for adenylate cyclase activity as described in the Materials and Methods section. Results are means \pm S.F.M. for three observations.

Additions to assay

p[NH]ppG (0.1 mM)

p[NH]ppG $(0.1 \mathrm{~mm})+$ corticotropin (1.5 units $/ \mathrm{ml})$

p[NH]ppG (0.1 mM)+glucagon $(1 \mu \mathrm{M})$

$\mathrm{p}[\mathrm{NH}] \mathrm{ppG}(0.1 \mathrm{mM})+\mathrm{L}$-isoproterenol $(10 \mu \mathrm{M})$

$\mathrm{p}[\mathrm{NH}] \mathrm{ppG}(0.1 \mathrm{mM})+$ corticotropin $(1.5 \mathrm{units} / \mathrm{ml})+$ glucagon $(1 \mu \mathrm{M})+\mathrm{L}$-isoproterenol

$(10 \mu \mathrm{M})$
Adenylate cyclase ( $\mathrm{nmol} / 20 \mathrm{~min}$ per $\mathrm{mg}$ of protein)

$8.6 \pm 0.28$

$7.5 \pm 0.19$

$8.65 \pm 0.23$

$8.65 \pm 0.40$

$7.65 \pm 0.11$ the first direct physical evidence for such a model. The value of the scheme lies in the wide range of experimental predictions that are opened up.

We thank Mr. John Green, Mr. Ronald Gouldstone and Mr. David Adams for operating the linear accelerator. This work was supported by grants from the Science Research Council to B. R. M. and from the Medical Research Council to J. M. S.

\section{References}

Birnbaumer, L. (1973) Biochim. Biophys. Acta 300, 129158

Birnbaumer, L., Pohl, S. L. \& Rodbell, M. (1972) J. Biol. Chem. 247, 2038-2043

Cassell, D. \& Selinger, Z. (1976) Biochim. Biophys. Acta 452, 538-551

Cuatrecasas, P. (1974) Annu. Rev. Biochem. 43, 169-214

Ellman, G. L., Courtney, K. D., Andres, V. \& Featherstone, R. M. (1961) Biochem. Pharmacol. 7, 88-95

Houslay, M. D., Metcalfe, J. C., Warren, G. B., Hesketh, T. R. \& Smith, G. A. (1976) Biochim. Biophys. Acta 436, 489-494

Houslay, M. D., Ellory, J. C., Smith, G. A., Hesketh, T. R., Stein, J. M., Warren, G. B. \& Metcalfe, J. C. (1977) Biochim. Biophys. Acta 467, 208-219

Kepner, G. R. \& Macey, R. I. (1968) Biochim. Biophys. Acta 165, 188-203

Kimura, N., NaKane, K. \& Nagata, N. (1976) Biochem. Biophys. Res. Commun. 70, 1250-1256

Lad, P. M., Welton, A. F. \& Rodbell, M. (1977) J. Biol. Chem. 252, 5942-5946

Levinson, S. R. \& Ellory, J. C. (1973) Nature (London) New Biol. 245, 122-123

Martin, B. R. \& Voorheis, H. P. (1977) Biochem. J. 161, 555-559
McKeel, D. W. \& Jarett, L. (1970) J. Cell Biol. 44, 417-432 Neer, E. J. (1974) J. Biol. Chem. 249, 6527-65.31

Newby, A. C., Rodbell, M. \& Chrambach, A. (1978) Arch. Biochem. Biophys. 190, 109-17

Orly, J. \& Schramm, M. (1976) Proc. Natl. Acad. Sci. U.S.A. 73, 4410-4414

Pfeuffer, T. (1977) J. Biol. Chem. 252, 7224-7234

Pfeuffer, T. \& Helmreich, E. J. M. (1975) J. Biol. Chem. 250, 867-876

Pilkis, S. J., Exton, J. H., Johnson, R. A. \& Park, C. R. (1974) Biochim. Biophys. Acta 343, 250-267

Rendell, M. S., Rodbell, M. \& Berman, M. (1977) J. Biol. Chem. 252, 7909-7912

Rodbell, M., Lin, M. C. \& Salomon, Y. (1974) J. Biol. Chem. 249, 59-65

Rodbell, M., Lin, M. C., Salomon, Y., Londos, C., Harwood, J. P., Martin, B. R., Rendell, M. \& Berman, M. (1975) Adv. Cyclic Nucleotide Res. 5, 3-29

Ross, E. M., Howlett, A. C., Ferguson, K. M. \& Gilman, A. G. (1978) J. Biol. Chem. 253, 6401-6412

Salomon, Y., Londos, C. \& Rodbell, M. (1974) Anal. Biochem. 58, 541-548

Schramm, M., Orly, J., Eimerl, S. \& Korner, M. (1977) Nature (London) 268, 310-313

Schulster, D., Orly, J., Seidel, G. \& Schramm, M. (1978) J. Biol. Chem. 253, 1201-1206

Sevilla, N. \& Levitski, A. (1977) FEBS Lett. 76, 129-134

Tolkovsky, A. M. \& Levitzki, A. (1978) in Hormones and Cell Regulation (Dumont, J. \& Nunez, J., eds.), vol. 2, pp. 89-105, North-Holland, Amsterdam

Welton, A. F., Lad, P. M., Newby, A. C., Yamamura, H., Nicosia, S. \& Rodbell, M. (1977) J. Biol. Chem. 252, 5947-5950

Welton, A. F., Lad, P. M., Newby, A. C., Yamamura, H., Nicosia, S. \& Rodbell, M. (1978) Biochim. Biophys. Acta 522, 625-639 